\title{
Tom Zé, a "Grande liquidação" e a perspectiva do migrante na tradição narrativa da canção paulistana ${ }^{1}$
}

Tom Zé, the "Grande liquidação" and the perspective of the migrant in the narrative tradition of the paulistan song

O presente trabalho foi realizado com apoio do ENPq, Conselho Nacional de Desenvolvimento Cientifico e Tecnológico - Brasil.

Bacharel em Comunicação Social - Jornalismo. Mestre em Letras pela Universidade Federa do Espirito Santo. Atualmente Doutorando em

Enil: gabrielcaiobor-0002-1160-8391
Gabriel Caio Correa Borges²

\author{
Programa de Pós-Graduação em Letras, Faculdade de Letras, Universidade Federal do Rio de Janeiro.
}

RESUMO: Aqui será proposta uma leitura à luz das ciências da literatura sobre as líricas do disco "Grande Liquidação", álbum de estreia do cantor e compositor Tom Zé. Interpretado conforme uma tendência quase conceitual, o disco será contemplado na proposta de trabalhar na canção certas narrativas sobre a cidade de São Paulo. Esse contexto é representado por Tom Zé ocupando um entrelugar, onde a vivência remete a formação como baiano que migra para a metrópole, porém reivindicando para si a tradição narrativa da canção paulistana. Essa tradição existe como rasto que alude às formações culturais paulistanas anteriores à modernização e que tem na narrativa cantada um de seus legados. Logo, iremos proceder na análise das canções do disco considerando essa conjuntura, que assim será compreendida através das teorias formuladas por Walter Benjamin sobre tradição narrativa.

Palavras-chave: Narrativa; São Paulo; Tradição; Migração; Tom Zé.

ABSTRACT: Here we should propose a lecture brightened by literature's science about the lyrics from the disc "Grande Liquidação", the debut album by the singer and composer Tom Zé. Taking as an almost conceptual album, will be consider in the purpose to make the songs as narratives around the city of São Paulo. From this context, Tom Zé stands between sites. His representations of the urban life communicate as someone born in the Brazilian state of Bahia who migrates to the metropolis, but acquires to himself the narrative tradition from the songs of São Paulo. This tradition shows as a trace back to old formations of the city early modern past which have as a legacy the chant narrative. So, we should proceed as listening the tracks with this context in mind, making the analysis by using the theories formulate by Walter Benjamin about the tradition and the narrative.

Abstract: Narrative; São Paulo; Tradition; Migration; Tom Zé. 


\section{Introdução}

$\mathrm{Q}$ ualquer um que se debruce sobre a música popular em São Paulo perceberá o quão foram determinantes para ela os diferentes movimentos migratórios que fundamentaram a transformação da capital paulista em metrópole. Em sua história de formação, essa musicalidade que concentra uma multiplicidade de artistas e dos gêneros musicais presentes na cidade carrega o rastro da migração em seus diferentes momentos. Alguns casos exemplares podem ser nomeados em Adoniran Barbosa e Paulo Vanzolini e seus sambas nas perspectivas de descendentes de italianos; o hino "Sampa" do baiano Caetano Veloso; o movimento da Vanguarda Paulistana liderado pelos paraibanos Arrigo Barnabé e Itamar Assumpção.

Conforme a canção paulistana é influenciada por esse fluxo migratório, deve-se considerar que tipo de canção foi formada seguindo esse fenômeno. É algo compreendido por Wisnik ao tratar dela no tipo de relação peculiar com São Paulo em comparação com outras cidades brasileiras. Por relacioná-la com a modernidade paulistana, Wisnik propõe que a principal característica desse cancioneiro foi se constituir em um espaço de síntese, onde a cultura de mescla ${ }^{1}$ surge de forma acentuada.

O lugar ambíguo que a música popular paulista ocupa no cenário nacional, ao mesmo tempo marcante e lateral, de quem está dentro e quem está fora, sem nunca sair completamente desta posição, é o mais imediato sinal da diferença. São Paulo é sobretudo uma metrópole do século 20 - não foi nicho de culturas orais e letradas plugadas no inconsciente colonial, como a Bahia desde o século 17, Minas desde o século 18, o

\footnotetext{
Sobre o conceito de cultura de mescla, é algo situado pela ensaísta argentina Beatriz Sarlo (2010) como algo proeminente daquilo que chama de modernidade periférica. Traçando a historiografia literária de Buenos Aires entre 1920 e 1930, ela suere esse fluxo de mescla cultural como um fenômeno tanto estético soción subdesenvolvido, que possibilitaria assim as sínteses mais dispares.
}

Rio de Janeiro no século 19. Isso faz uma enorme diferença no modo como a música se entranha na vida popular, e no modo como se formaram e decantaram gêneros musicais. Com exceção da música caipira, guardada tradicionalmente na voz encorpada e reta de Inezita Barroso, em São Paulo não se criaram os gêneros. Aqui eles se encontram, se misturam, se desmancham, são processados e reprocessados, e tratados muitas vezes com aquela distancia relativizante de que se investem as coisas quando são sabiamente de empréstimo (WISNIK, 2004, p. 303).

Se Wisnik percebe um fator importante na formação musical paulistana, desacredita outro, porém. Afinal, sua constatação de São Paulo como ponto de encontro cultural é indissociável da noção da modernidade como fenômeno desenraizador por excelência. Para que a cidade encarnasse essa condição ela estaria destituída de qualquer tradição anterior. É um pressuposto bem justificado, pois São Paulo se apresenta exatamente como a metrópole da novidade. Seu poder de erguer novos edifícios é análogo à desintegração e à destruição constantes que criam esses novos monumentos, cujo paradoxo ${ }^{2}$ remete ao destino de também se degradarem em ruínas em um futuro próximo ${ }^{3}$. É uma condição do espaço que se espalha sobre os encaminhamentos da vivência urbana; da percepção ideológica como

2 Compreendemos como paradoxo, pois se tem em conta que o significado do termo monumento remete acima de tudo a um estandarte do passado, um símbolo de memória que dura através do tempo. Como alude à etimologia o historiador Jacques LeGoff, o termo monumento provém do termo latino monumementum que "remete à raiz indo-européia men, que exprime uma das funções essenciais do espírito (mens), a memória (memini). O verbo monere significa 'fazer recordar', de onde 'avisar',
'iluminar', 'instruir'” (LEGOFF, 2013, p. 487).

3 Uma constatação bem apurada desse fenômeno, que é ao mesmo tempo um relato sobre sua vida São Paulo, foi bem elaborado por Claude Levi-Strauss ao perceber os rumos do desenvolvimento moderno nas metrópoles do continente americano.

Certas cidades da Europa adormecem suavemente na morte; as do Novo Mundo vivem febrilmente uma doença crônica; eternamente jovens, jamais são saudáveis, porém.

Ao visitar Nova Iorque ou Chicago em 1941, ao chegar em São Paulo, em 1935, não foi, portanto, o aspecto novo que de início me espantou, mas a precocidade dos estragos do tempo. Não me surpreendeu que a essas cidades faltassem dez séculos, impressionou-me verificar que tantos bairros já tivessem cinquenta anos; que, sem pejo, alardeassem tais estigmas, visto que o único encanto a que poderiam aspirar seria o de uma juventude fugaz tanto para eles quanto para os vivos (LEVI-STRAUSS, 1996, p. 92). 
cidade do "progresso" até a vida comunitária quebrada, impossibilitada de estabelecer raízes, pois o espaço se redefine constantemente.

Logo, Wisnik tem suas razões para diferenciar São Paulo de outros celeiros musicais urbanos, donde o florescimento da música popular se relacionou com uma evolução da mesma dentro de certa tradição. Contudo, a identificação de um cenário adverso à manutenção de tradições não é suficiente para afirmar a sua inexistência. Pois se a metrópole se situa como ponto de encontro de certo cosmopolitismo cultural, nada impede que em seu meio se encontre os rastros de alguma tradição local remanescente dos tempos pré-modernos. Isso ocorre mesmo em São Paulo, que não apenas teve esse rastro documentado pela etnografia, como também deixaria sua marca na canção da cidade como imprescindível exatamente na formação de sua identidade urbana.

Sugere-se que o sentido de uma tradição pode ser encontrado exatamente na própria narrativa cantada sobre São Paulo. Mais especificamente no que bebe da fonte dos chamados Sambas de Bumbo e das Modinhas Paulistanas. Duas manifestações que se formam no limiar da transição do paradigma agrário para o moderno e que atuaram na espontaneidade possível em um campo em decadência e em uma urbanidade ascendente. Ora tentando estabelecer uma tradição comunitária, como no caso do Samba de Bumbo, ora no desmembramento de sua possibilidade, como nas modinhas paulistanas, ambos os fazeres trataram a narrativa como sendo inseparável da canção. É um detalhe perceptível nas pesquisas de Mário de Andrade (1975) e Antônio Alcântara Machado (1935) sobre essas manifestações. Ao tomarmos dois fazeres diferentes como origem de um legado narrativo, o ressaltaremos como tradição, ainda que enfatizando seu aspecto como rastro. Pois como se deve assumir que muito dela se alterou e se perdeu em meio à modernidade urbana, sua movência remete à possibilidade de encontro e mescla com outros fazeres que é peculiar de metrópoles como São Paulo.

\section{Narrativa e Experiência}

Quando se trata da relação entre narração, tradição e modernidade, deve-se remeter às teorias fundamentadas por Walter Benjamin acerca da narrativa oral. Benjamin (2012) associa essa formação narrativa à transmissão de uma experiência tradicional (erfahrung), cujo fundamento alude à vida comunitária pré-moderna e que estabelece na tradição uma correlação entre sociabilização e estética. Estabelecendo uma dinâmica entre solidez comunitária com renovação geracional, a condição da narrativa como significadora da experiência relaciona sua base na tradição com a possibilidade de renovação da mensagem através do tempo. Benjamin exemplifica essa força da narrativa na história de Heródoto sobre um rei egípcio que, capturado por uma nação inimiga, assiste apático à escravização de seus parentes, mas só se agita quando testemunha um criado na posse dos adversários.

Ela [nota do autor: a narrativa] não se esgota jamais. Ela conserva suas forças e depois de muito tempo ainda é capaz de desdobramentos. Assim, Montaigne retornou a história do rei egípcio, perguntando: por que ele só se levanta quando reconhece o seu servente? Sua resposta é que ele 'já estava tão cheio de tristeza que uma gota a mais bastaria para derrubar as comportas'. É a explicação de Montaigne. Mas poderíamos também dizer:

'O destino da família real não afeta o rei, porque é o seu próprio destino'. Ou: 'muitas coisas que não nos afetam na vida nos afetam no palco, e para o rei, o criado é apenas um ator' Ou: 'as grandes dores são contidas e só irrompem quando ocorre uma distensão'. Heródoto não explica nada. Seu relato é dos mais secos. Por isso, essa história do antigo Egito ainda é capaz, depois de milênios, de suscitar espanto e reflexão (BENJAMIN, 2012, p. 220).

Ao contextualizar essas teorias da narrativa com um panorama das ideias gerais de Benjamin sobre história e linguagem, Jeanne Marie Gagnebin (2013) relaciona esse movimento de significação naquilo que 
remete às qualidades da alegoria. Compreendida na alteração do signo através da distância do tempo, a alegoria é ressignificada conforme se dissipam suas origens, apagadas e ocultadas pelo movimento da história, no estabelecimento de sua condição como rastro ou ruína. Ao se confrontar com um documento cuja origem desaparece, reconhecer seu valor alegórico implica a reescritura do significado que envolve determinar um elo entre o passado que desvaneceu e o presente. Por submeter o processo de significação ao movimento da história, à alegoria foi frequentemente contraposta o símbolo, considerado na possibilidade de apreender o significado da origem. Porém, em consonância com as teorias benjaminianas, essa oposição seria falsa, julgando que o papel do símbolo na significação seria o de capturar o momento onde o significado se apresenta pleno.

O que importa, entretanto, nesse paralelo entre símbolo e alegoria é onde lhes é reconhecido o seu valor na modernidade. Pois se a modernidade é o período onde a sina de tudo é ser reduzido a ruínas, interpretar não apenas o passado distante, mas também o próximo, surge como exercício de formação de alegorias sobre o tempo no qual estamos sujeitos. É algo que fica mais complexo conforme se entende a relação da modernidade e a narrativa. Afinal, é notório que das considerações de Benjamin sobre o narrador, o ato de narrar tem ficado raro até silenciar enfim nas guerras mundiais. Isso não é levado por um fim da transmissão do rastro, mas sim da impossibilidade de estabelecer um ponto de origem para uma novidade alinhada com a violência, destruindo qualquer esperança de assimilar uma experiência.

Uma das causas desse fenômeno é evidente: as ações da experiência estão em baixa. E tudo indica que continuarão caindo em um buraco sem fundo. Basta olharmos um jornal para nos convencermos de que seu nível está mais baixo que nunca, e que da noite para o dia não somente a imagem do mundo exterior mas também a do mundo moral sofreu transformações que antes teríamos julgado como absolutamente impossíveis. Com a guerra mundial começou a tornar-se manifesto um processo que desde então segue ininterrupto. Não se notou que, ao final da guerra, que os combatentes voltavam mudos do campo de batalha; não mais ricos, e sim mais pobres de experiência comunicável? E o que se derramou dez anos depois, na enxurrada de livros sobre a guerra, nada tinha em comum com uma experiência transmitida boca a boca. E não havia nada de anormal nisso. Porque nunca houve experiências mais radicalmente desmentidas que a experiência estratégica pela guerra de trincheiras, a experiência econômica pela inflação, a experiência do corpo pela batalha material e a experiência moral pelos governantes (BENJAMIN, 2012, p. 214).

Assim se lida com uma realidade cruelmente irônica, onde o gênero formado através da alegoria se percebe impedido na era do arruinamento constante, cuja consagração à novidade remete sempre a um envelhecimento fugaz. O desafio da linguagem na modernidade, assim como em resistência a esta, é justamente o de reestabelecer o relato onde laços comunitários foram desfigurados, os sentidos ofuscados e o estranhamento elevado à ordem cotidiana. No que há de dialético em abrir essa possibilidade, interessa que a mesma condição que emudeceu a narrativa pode ser a mesma a recriá-la. A experiência vivida (erlehbinis), ou simplesmente vivência, é a situação dos passantes que encaram a solidão atomizada nas metrópoles, cujo cotidiano é definido tanto pela previsibilidade da rotina quanto pela surpresa da mudança frequente. Sempre apresentada em um entrelugar, indefinida e sem identidade no qual se amparar, a vivência surge como efeito dessa modernidade quebrantada; ela pode, porém, remontar os cacos daquilo que foi arruinado em seu movimento. Das possibilidades assim abertas, isso não corresponde a reconstituir a velha experiência comunitária. Ao contrário, trata-se do desafio de fundar nas suas ausências exatamente aquilo que lhe falta: fazer do desterro uma identidade, do esquecimento uma memória, do silêncio um relato. Trata-se de algo que seria encontrado na literatura modernista da primeira metade do século XX, mais especificamente em Kafka. 
Essa bela história ${ }^{4}$ nos introduz aquilo que poderia chamar, segundo Benjamin, a mais perfeita narração contemporânea da impossibilidade de narrar. As qualidades do narrador tradicional voltam, distorcidas, invertidas, numa espécie de deformação irônica e dolorosa cuja expressão toda a obra de Kafka configura. Assim, em vez de prodigar conselhos, Kafka é, sim, um 'grande narrador', mas que 'teria comunicado aos outros a sua desorientação' (ratlosigkeit). Com efeito, ele possui 'a vantagem inestimável de ser semelhante ao narrador tradicional', de não intervir na sua narrativa, de não pretender originalidade nenhuma, de ser esta voz 'neutra' que Blanchot descreveu admiravelmente, enfim, se fazer esquecer, mas todas essas qualidades que o narrador tradicional tirava da rica tradição na qual se enraizava, Kafka, por sua parte as conquistou a duras penas no terreno solapado da tradição morta e de uma identidade em migalhas (GAGNEBIN, 2013, p. 66).

A situação da narrativa na modernidade, sugerida pelo exemplo de Kafka, surge da problemática de elaborar um discurso que signifique o inexprimível. Interessa como essa condição elevada à regra não sedimentou por completo uma ordem do esquecimento, mas permitiu à alegoria resgatar sua ligação com a verdade. Afinal, no entendimento de Benjamin (2009) a preocupação com a verdade é algo cuja linguagem só pode estabelecer com aquilo que lhe escapa: silêncios, cesuras, quebras e interrupções. Logo, o que é denominado como sem expressão estabelece dialeticamente uma relação mediadora entre a necessidade do discurso e a verdade oculta das coisas. Abre um caminho na possibilidade de dar forma ao caos, mas obriga o harmônico a entrar em movimento.

A dubiedade que se sobressaiu no sem expressão elevado à quintessência do discurso é assim proposta, pois para recriar a narrativa esta teve de se despir da pretensão daquela experiência coesa que marcava a tradição. Isso obriga a narrativa a aprofundar a relação entre alegoria e anacronismo para possibilitar a transmissão; assumir a condição da memória como rastro de

4 Referência ao conto de Kafka "Uma Mensagem Imperial" um passado retornável para presentificá-lo como símbolo é cair na projeção (GAGNEBIN, 2013). Ademais, se a condição da modernidade é a de se reconstruir reduzindo o novo a escombros, mesmo o passado próximo se vê condicionado a ser alegoria.

\section{Tom Zé e a canção narrativa sobre São Paulo}

Essas considerações surgem tanto como base quanto como problema para nossa inquirição, pois ao reconhecermos a influência da narrativa tradicional na formação da moderna canção paulistana, isso não significa, contudo, que a tradição foi continuada. O resgate de seu rastro é um reconhecimento de sua distância no tempo, aparecendo como resistência não só da possibilidade de apagamento fulminante dele, mas também do seu valor naquilo que é ausente na modernidade. Interessa-nos como remeter a esse rastro na colcha de retalhos desse cancioneiro significou diversas formas de confrontar a vivência em uma cidade como São Paulo. Para as primeiras gerações de músicos populares retomar a narrativa indicava a memória viva das formações comunitárias pré-modernas da cidade e arredores. Mas é notável a ação de compositores provindos do êxodo de outros estados e regiões que migraram para a metrópole nos anos 50 e 60 por se apropriar desse legado narrativo e contribuir para a crônica sobre São Paulo. É algo que enfim nos leva ao jovem Tom Zé, cuja fase inicial demonstra uma dedicação especial em musicar a vivência paulistana nas miudezas de significados que ela pode suscitar. Situando-se no lugar daquele que se desenraiza da terra de origem, a cidade de Irará na Bahia, e procurando elaborar uma identidade condizente com a metrópole no qual se assenta, Tom Zé assim representou aquele aspecto sintético da vivência. É algo que, aliás, pode ser extraído da sua formação musical, conforme se revela de um encontro com Adoniran Barbosa, relatado na biografia sobre este. 
Angélica, Augusta e Consolação, uma das canções de seu recém-lançado LP Todos os Olhos, foi dedicada no encarte a Adoniran e aos Demônios da Garoa. 0 franzino compositor nordestino, que ouvira pela primeira vez as músicas do paulista nos alto-falantes de Irará, sua cidade natal no Recôncavo Baiano, já havia tido a oportunidade de mostrar a obra em primeira mão ao inspirador. Alguns anos antes, no prédio da própria Tv Record, Tom Zé cantava ao mestre a letra da canção, na qual as tradicionais vias de São Paulo apareciam como personagens femininas envolvidas em um quadrilátero amoroso com o narrador (CAMPOS JR., 2004, p. 476).

Esse episódio que combina um momento do compositor consagrado com sua memória como ouvinte revela a formação moderna de um músico que cresce em um período de mudanças, onde os principais polos de culturas de massa expandem constantemente sua influência nos grotões do país. Portanto, sua proposta de tematizar São Paulo vem do encontro entre a cidade pequena natal com a metrópole industrializada no qual se dirige, com a canção servindo como ponto de convergência. É uma condição que apareceu junto do papel do compositor no tropicalismo e o marcou como parte da canção crítica, do músico popular que também se apresenta como intelectual e incorpora a reflexão ao próprio cancioneiro (NAVES, 2012). Em Tom Zé, a cidade de São Paulo é figurada não apenas para refletir sobre a vivência moderna, mas também do potencial da canção para se constituir como narrativa urbana.

Isso é perceptível em seu álbum de estreia, "Grande Liquidação", cuja onipresença de São Paulo na totalidade das canções quase que poderia qualificar a obra como conceitual. Do que perpassa a audição desse disco - cujos ecos podem ser ouvidos no seminal álbum-manifesto "Tropicália ou Panis et Circencis", por conta da inclusão de "Parque Industrial" - a ideia é utilizar do aspecto sintético do tropicalismo para conciliar criticamente o teor vanguardista moderno de São Paulo com os sussurros da narrativa tradicional herdados do cancioneiro paulistano.
Ademais, se Tom Zé assume a influência de artistas como Adoniran Barbosa, chama atenção como o teor da perspectiva sobre São Paulo é essencialmente humorístico. É algo que envolve principalmente sua faceta crítica, pois transparece nessa obra inaugural o uso da ironia e da irreverência ao descrever personalidades típicas paulistanas. Sobre a ironia, o passo decisivo que Tom Zé dá na proximidade do tropicalismo com o cancioneiro paulistano é assumir as idiossincrasias da vivência na metrópole naquilo que ela expõe como ridículo ou tacanho. 0 compositor deixa isso claro na faixa de abertura, "São São Paulo", cuja declaração de amor contida no refrão é contrastada com imagens do turbilhão caótico urbano, onde a condição atomizada do indivíduo é ressaltada.

São oito milhões de habitantes
De todo canto em ação
Que se agridem cortesmente
Morrendo a todo vapor
E amando com todo ódio
Se odeiam com todo amor
São oito milhões de habitantes
Aglomerada solidão
Por mil chaminés e carros
Caseados à prestação
Porém com todo defeito
Te carrego no meu peito
São, São Paulo
Quanta dor
São, São Paulo
Meu amor (TOM ZÉ, 1968).

A descrição crua dos choques de uma metrópole que se faz moderna, cujo fluxo intenso interrompe qualquer esperança de relação amistosa, é abrandada com o porém afetuoso do músico. Esse gesto em algo cristão "redime" São Paulo de sua modernização ao mesmo tempo a assume como 
condição de uma nova identidade. Isso é sugerido na lírica conforme o choque entre indivíduos é ressaltado na formação do cosmopolitismo paulistano. Se a constatação é de que essa multiplicidade humana e cultural é instável, desarmônica e volúvel, incapaz de estabelecer qualquer coisa, a ironia surge como o movimento que permite extrair disso o seu oposto, se sentir em casa nesse cenário. Tom Zé assim se assemelha com os grandes romancistas que utilizam da ironia como recurso ético e estético, compreendendo as contradições do íntimo diante da realidade despedaçada da modernidade. É algo que foi constatado por Lukács em sua famosa teoria do romance.

De fato, a ironia desdobra-se em ambas as direções. Ela apreende não apenas a profunda desesperança dessa luta, mas também desesperança tanto mais profunda de seu abandono - o deplorável fracasso de uma desejada adaptação a um mundo alheio a ideais, de um abandono da irrealidade ideal da alma em prol de um controle da realidade. E na medida em que configura a realidade como vencedora, a ironia revela não apenas a nulidade do mundo real diante de seu adversário derrotado, não apenas que essa vitória jamais pode ser definitiva e será reiteradamente abalada por novas insurreições da ideia, mas também que o mundo deve sua primazia menos à própria força, cuja grosseira desorientação não basta para tanto, do que a uma problemática interna - embora necessária - da alma vergada sob os ideais (LUKÁCS, 2009, p. 87).

O retrato ácido que Tom Zé faz da vivência paulistana para imediatamente responder a ela com sua afabilidade é condizente a esse jogo duplo da ironia percebido por Lukács. Pois, ao declarar seu amor pela cidade, mas pela adversativa relevar seus ditos defeitos, o compositor estabelece que sua paixão exerça igualmente certo ódio, repulsa pela cidade que adotou. E isso não apenas para os percalços do eu lírico diante do panorama do turbilhão urbano, mas para a própria São Paulo em si e em seus significados evocáveis. Isso vale principalmente para a antítese do movimento da modernidade, a tradição que tenta resistir e se conservar de forma anacrônica. Se por um lado Tom Zé deve algo aos sambistas e cancionistas paulistanos remetentes de um rastro antepassado da canção e da narrativa na cidade, por outro o lado opressivo da tradição, com seus signos de autoridade e de moral, não é ignorado pelo compositor. Digase que quando o termo "tradição" aparece na lírica é representado como parte dessas coisas instáveis e decadentes que surgem na cidade tal como as "mil chaminés e carros".

Portanto, não é coincidência que São Paulo pareça ser o lugar ideal para encontrar um alvo frequente das paródias tropicalistas: o conservador de classe média. $\mathrm{O}$ tipo que teve o conformismo imortalizado por Caetano Veloso e Gilberto Gil em "Panis et Circencis" é recorrente na estreia de Tom Zé como alegoria do próprio mal-estar que a modernidade paulistana perpassa. o compositor percebeu que a questão da moral em sua relação com a época serve como termômetro para medir a sensação de pertencimento e desolação do indivíduo na metrópole. Isso permite apresentar a questão na segunda estrofe de "São São Paulo", onde a tensão moral proporcionada pela visão das prostitutas é exemplar dos choques frequentes a que os cidadãos são submetidos.

Salvai-nos por caridade

Pecadoras invadiram

Todo centro da cidade

Armadas de rouge e batom

Dando vivas ao bom humor

Num atentado contra o pudor

A família protegida

0 palavrão reprimido

Um pregador que condena

Uma bomba por quinzena

Porém com todo defeito

Te carrego no meu peito (TOM ZÉ, 1968). 
Esse fragmento lírico mais aberto e difuso introduz as críticas do moralismo e da "tradição" que serão colecionadas ao longo de "Grande Liquidação". Da norma onde o teor irônico beira o método, atacar essas figuras morais que projetam uma segurança enganadora contra os choques da modernidade traz oportunidades para Tom Zé se aproximar da narrativa do cancioneiro paulistano. São diversos personagens cujo conflito gira na sombra das expectativas da moral tradicional concomitantemente ao renegarem a mesma; consciente ou inconscientemente.

Todavia, das encarnações possíveis da temática moral, deve-se destacar as projeções geracionais que o compositor faz dela. "Namorinho de portão", enfocada em um jovem singelo, e "Glória", na perspectiva de um pai autoritário, relacionam moralismo e geração no que coaduna com a representação da época das composições. Aspecto que nas turbulências da década de sessenta, a crítica intentada é inseparável do comentário sobre as aspirações conservadoras da ditadura militar. "Namorinho de portão" deixa evidente essa relação. 0 protagonista, cantado no refrão como um "Bom rapaz/ direitinho" que "desse jeito não tem mais" (TOM ZÉ, 1985), molda a si mesmo para corresponder às expectativas dos familiares da parceira. A correspondência do ambiente familiar como sufocante e opressivo, onde o sujeito deve anular a si mesmo para nele se integrar, é comparada a um filme censurado.

Namorinho de portão

Biscoito, café

Meu priminho, meu irmão

Conheço essa onda,

Vou saltar da canoa

Já vi, já sei

Que a maré não é boa

É filme censurado

E o quarteirão

Não vai ter outra distração (TOM ZÉ, 1968).
A equivalência entre a confraternização familiar e um filme censurado enfatiza a noção de artifício castrador, onde a situação que deve perpassar um idealismo moralista surge como algo forçado, onde cada qual deve atuar em um papel pré-determinado que reprime a subjetividade. É interessante que conforme se aprofunda na comparação proposta, é logo sugerido que o imperativo de papéis seguidos naquele ambiente privado é o entretenimento da vizinhança que assiste afastada. Os percalços da intimidade familiar contemplados como filme, como espetáculo. Demonstração de que a ironia de Tom Zé estava bem alinhada com as ideias em voga no período de agitação sessentista. É o que o leva a se aproximar do conceito de sociedade do espetáculo, formulado por Guy Debord (1997), que compreende um estágio de sujeição do cotidiano ao capitalismo que impõe a mediação sobre a percepção da vivência. A relação entre sujeito e meio, entre indivíduo e sociedade é assim reduzida ao espetáculo, logo uma falsificação constante. A compreensão de tirania espetacular, onde tudo vira aparência, casa com a da ditadura militar, cuja imposição do filme censurado existe para falsificar uma situação de normalidade. 0 moralismo, em seus apelos e suas expectativas, mas também onde deseja esconder o que há de falho e de decadente, é o conteúdo modelo do autoritarismo, naquilo onde o cidadão ideal da vida pública é aquele dos regramentos ditosos da vida privada. 0 engodo que o protagonista de "Namorinho de Portão" tem de suportar é exatamente o da aparência de normalidade dessa moral privada, onde se espera de cada um certo comportamento padrão.

$$
\begin{aligned}
& \text { A vovó no tricô } \\
& \text { Chacrinha, novela } \\
& \text { O blusão do vovô } \\
& \text { Aquele tempo bom que já passou } \\
& \text { E eu de "é", de "sim", de "foi" (...) } \\
& \text { O papai com cuidado } \\
& \text { Já quer saber sobre o meu ordenado }
\end{aligned}
$$


Já pensa no futuro

E eu ando tão duro

Não dou pra trás

Entro de dólar e tudo

Pra ele o mundo anda muito mal

Lá vem conselho coisa e tal (TOM ZÉ, 1968).

Se a imposição moral para o jovem corresponde ao prosseguimento de um império de aparências cuja previsibilidade beira o rotineiro, a identificação do eu lírico para o patriarca em “Glória" se volta ao caminho oposto, no desmonte dessa ordem em suas aplicações no discurso. É revelador como a figura paterna é eficiente para esmiuçar a relação entre moral e poder. Afinal, da perspectiva daquele que transmite e impõe certo imperativo moral, a qualidade de farsa desta se faz evidente. E de estorvo também, pois na selvageria competitiva da modernidade capitalista, não se deve ter receio em sacrificar os valores morais para ter o sucesso como fim.

Ensinou-lhes bem cedo a defender

a família e a tradição

balançando a bandeira do bem

o pecado punir sem perdão.

Mas nos seus pequenos erros

preferir a casa alheia

ressalvando a discrição

e tudo isso ensinou

com poucas palavras

e muitas ações.

Ensinou-lhes bem cedo que a honra

todos devem cultivar

entretanto, ao tomar decisões

ela nunca deve atrapalhar.

Mostrou que as boas razões

a causa justa é que é nobre

convive é com os milhões

e tudo isso ensinou

com poucas palavras

e muitas ações (TOM ZÉ, 1968).
A imagem desse pai naquilo que remete à figura de força sugerida pela autoridade masculina, porém ressaltando sua ambiguidade, leva inevitavelmente a considerações sobre o ocaso da moral - e, consequentemente, da tradição - conforme a modernidade avançou. Afinal, daquilo que se extrai da formação moral na construção do edifício civilizatório ocidental, os mesmos se confundem na expressão de força do cristianismo. Se erguendo em cima das ruínas da civilização greco-romana, o que o cristianismo consolidou através da alegoria da crucificação foi à negação do humano em sua natureza. Disso decorreu daí a valorização da fraqueza e da abnegação como fundamentos morais que serviram de base para a civilização cristã ocidental por milênios. Se Nietzsche (2009) percebe tudo isso ao realizar sua investigação sobre as concepções de moral e dos valores dela provenientes, ele também entende, porém, que a complexidade da moral cristã contém também o germe do seu ocaso. Pois conforme das noções valoradas pela moral cristã, a de verdade, que a princípio negava as outras deidades sob a luz do monoteísmo, consumiu o mesmo conforme deu vazão ao desencantamento do mundo.

Desta maneira pereceu o cristianismo como dogma, por obra de sua própria moral; desta maneira, também o cristianismo como moral deve ainda perecer - estamos no limiar deste acontecimento. Depois que a veracidade cristã tirou uma conclusão após a outra, tira enfim sua mais forte conclusão, aquela contra si mesma; mas isso ocorre quando coloca a questão: "que significa toda vontade de verdade?".. E aqui toco outra vez em meu problema, em nosso problema, meus caros, desconhecidos amigos (- pois ainda não sei de nenhum amigo!) que sentido teria nosso ser, senão o de que em nós a vontade de verdade toma consciência de si mesma como problema?... Nesta gradual consciência de si da vontade de verdade - disso não há dúvida - perecerá doravante a moral: esse grande espetáculo em cem atos reservados para os próximos dois séculos da Europa, o mais terrível, mais discutível e talvez o mais auspicioso entre todos os espetáculos (NIETZSCHE, 2009, p. 139). 
Se a definição da modernidade é exatamente essa tendência iluminista da verdade, naquilo que é capaz de arruinar mesmo a mítica que lhe origina, nada mais representativo do seu movimento contraditório do que o pai em "Glória". Sua presença kafkiana, que educa "com poucas palavras e muitas ações", remetem à impostura da moral familiar que deve ser marcada permanentemente nos filhos, mas que leva finalmente a sua negação. Ademais, interessa que no reboco dos valores da moralidade cristã e seus negativos como "família", "bem" e "pecado" surja o signo da tradição no conjunto. Indicativo de como a tradição e a transmissão que ela representa são importantes para a moral, assim como é a moral que ressignifica a experiência pedagógica da tradição. Ver no patriarca, atribuído como guardião dos valores e seu transmissor para as gerações posteriores, jogar seus atributos por terra, mensura que tradição e moralidade caem necessariamente juntas.

Diante da queda dos velhos estandartes, o que resta de apoio ao cidadão na desolação urbana? Tom Zé, assim como Adoniran Barbosa antes dele, contemplou algumas alternativas. O cinismo paternal em "Glória" já compreende uma possibilidade bem cogitada ao longo do disco. A malandragem, essa busca por atalhos em meio aos regramentos da vivência na cidade, é considerada frequentemente pelo compositor como uma forma de resistência. Se é verdade que a figura do malandro é um arquétipo comum na canção popular brasileira, em São Paulo ela ganha outro peso, pois proporciona uma contrapartida à certa ideologia local. Se o processo de modernização paulistana surpreende pela velocidade de seu crescimento, o que se articula daí é a tentativa não apenas de fazer São Paulo ser fiel a uma identidade moderna, mas também o exemplo nesse quesito. Na circunstância histórica com que se deu esse desenvolvimento no século XX, o fenômeno da modernização conservadora da cidade tenciona com a formação geral do país, especialmente durante os governos de Vargas. Isso leva a projetar São Paulo como algo excepcional sobre o resto do Brasil, na mítica de um
Oasis de modernidade encravado em um país atrasado. 0 que se assim se desenha como ideologia dominante em São Paulo é um misto de exaltação daqueles valores abstratos da modernidade, como progresso e trabalho, com um sentimento missionário que idealiza o passado bandeirante da cidade. Essa perspectiva excepcionalista da modernidade paulistana se converte em ideologia de poder no interior da metrópole, onde ela é exaltada em eventos de celebração e em anúncios publicitários. Quem vive em São Paulo é lembrado constantemente de que estar na metrópole é mais que um pertencer, mas uma missão.

Nessa perspectiva, se a metrópole de São Paulo encarna a mais legítima representação do progresso, o paulista, portanto, define-se como aquele que, indubitavelmente, dispõe do tempo em prol do impulso rumo à civilização. Essas considerações conduzem ao delineamento da identidade do habitante desta cidade a partir de articulações significativas entre progresso e trabalho. Portanto, "o jeito de ser paulistano", legitimado pela ordem dominante, é tecido por representações derivadas da lógica que ordena o mundo do trabalho/produção na sociedade industrial (ROCHA, 2002, p. 79).

Oferecer um contraponto ao ufanismo reificador é algo que Tom Zé continua da canção popular paulistana, cuja recuperação do rastro narrativo sugere a ascensão de outro discurso, que compreende as experiências anuladas na retórica do poder. Também permite captar as sutilezas e os silêncios que transbordam dessa retórica, permitindo vislumbrar sua verdade avulsa. A sátira é um dos veículos que permite evidenciar essa potência do oculto ao expor aquilo que há de ridículo no discurso. Logo, seguindo o exemplo que seu ídolo havia realizado em "Conselho de Mulher", Tom Zé parodia o ufanismo paulistano na icônica canção "Parque Industrial". É interessante que o fato dessa faixa se encontrar tanto no álbum de estreia Tom Zé quanto no disco manifesto do tropicalismo demonstra o alinhamento dessa sátira com o espírito da época. Ou melhor, de como a exaltação de 
São Paulo como terra modernizadora rima com os projetos de país encampados pela ditadura militar.

Retocai o céu de anil

Bandeirolas no cordão

Grande festa em toda a nação

Despertai com orações

0 avanço industrial

Vem trazer nossa redenção

Tem garota-propaganda

Aeromoça e ternura no cartaz

Basta olhar na parede

Minha alegria

Num instante se refaz

Pois temos o sorriso engarrafadão

Já vem pronto e tabelado

É somente requentar

E usar

É somente requentar

E usar

Porque é made, made, made, made in Brazil

Porque é made, made, made, made in Brazil (TOM ZÉ, 1968).

A lírica traça uma pintura de um Brasil que se converte em uma nação moderna e industrializada, cumprindo o projeto encampado em São Paulo para todo o país. No retrato de um Brasil ideal ambicionado tanto pela elite empresarial paulistana quanto pelo autoritarismo militar, o projeto de país não difere da representação estática de uma propaganda. Em afinidade com o "sorriso engarrafado", as peças comerciais que exaltam a modernidade paulistana colhidas pelo trabalho de Francisco Rocha (2002) surgem como precursoras das fotos turísticas que vendiam um país em vias do progresso durante a ditadura militar.

Nesse contexto onde bairrismo com ares modernizantes combina com o projeto de desenvolvimentismo militarista nacional, inserir nele a persona do malandro é perturbar um ordenamento que se mantém pela aparência de harmonia presente e futura. Pois o malandro não apenas é o inimigo per se dessa ordem, encarnando em si os valores repudiados por quem idealiza o progresso e o trabalho, mas também é daqueles tipos representam a vivência aventurosa na cidade. Tomando a construção desse personagem conforme suas atribuições sócio-históricas nacionais, Antônio Cândido (2010) situa o malandro no cerne da dialética da ordem e da desordem. Sua amoralidade, mais do que o contraponto ao Estado, seus agentes e aos fetichistas da ordem, se comunica com a formação de um país definido por não conseguir estabelecer uma identidade moral unificadora. Ao realçar nossa falha de impor um caráter moral, o malandro sugere em sua personalidade o feitio de multiplicidade e mistura que atravessam o brasileiro como povo. Nada mais significativo que o malandro seja figura tão frequente na arte popularesca ou influenciada por esta.

A personalidade do malandro é recorrente conforme o compositor assume o eu lírico, se inserindo na narrativa proposta na canção. Assim, assumir o malandro remete a incorporar como identidade aquilo que aponta tanto para a multiplicidade étnico-cultural brasileira quanto alguém aberto a ser preenchido. No que reage ao complexo urbano e às consequências ulteriores da modernidade, o malandro aponta para explorar novos potenciais desse espaço e tempo indefinidos; naquilo onde se tentar administrar e ordenar também dá margem à liberdade e ao caos. Ser malandro, portanto, significa ser fiel aquela experiência vital que Marshall Berman utilizou para definir a modernidade naquilo que ela tem de dialético.

Existe um tipo de experiência vital - experiência de tempo e espaço, de si mesmo e dos outros, das possibilidades e perigos da vida - que é compartilhada por homens e mulheres no mundo, hoje. Designarei esse conjunto de experiências como 'modernidade'. Ser moderno é encontrarse em um ambiente que promete aventura, poder, alegria, crescimento, autotransformação e transformação das coisas em redor - mas ao mesmo tempo ameaça destruir tudo que temos, tudo que sabemos, tudo que somos (BERMAN, 1984, p. 15). 
Tom Zé situa seu aspecto malandro exatamente nessa existência aventurosa que coincide as características desse personagem com as expectativas da modernidade. Porém, ele aprofunda-se nessa relação, se utilizando dela para ligar seu presente paulistano à formação no velho município baiano onde nascera. Esse retrato é descrito na autobiográfica "Catecismo, Creme Dental e Eu", onde a criação desamparada, que sugere contornar um meio hostil constantemente, transita dos símbolos do agrarismo nordestino para os da vivência paulista.

Vou morrer nos braços da asa branca,

No lampejo do trovão

De um lado ladainha,

Sem soluço e solução.

Nasci no dia do medo

Na hora de ter coragem

Fui lançado no degredo

Diplomado em malandragem

Caminho, luz e risco,

Aflito,

Xingo, minto, arrisco, tisco,

E por onde andei

Eu encontrei o bendito fruto em vosso dente,

Catecismo de fuzil

E creme dental em toda a frente.

Pois um anjo do cinema

Já revelou que o futuro

Da família brasileira

Será um hálito puro.

Pinta -la - inha

Da cana vintinha

Mandei dizer pro meu amor

Faça a cama na varanda

E não esqueça o cobertor

Não quero ser cantador

Só fazer valentia

Também gasto heroísmo

Nos braços de uma Maria (TOM ZÉ, 1968).
É um caminho caótico onde as imagens do arcaico e do moderno se concatenam, se encostam e se fundem, o que leva a identidade do malandro a uma definição que indica antes de tudo sobrevivência. Ser "diplomado em malandragem" se encontra como predisposição a continuar vivendo, em vista que a iniciação no meio já decorre logo após o nascimento. Sua existência é antes de tudo tática, naquilo que foi assim delimitado por Michel de Certeau (1994) sobre o sujeito que busca contornar e driblar no espaço as imposições estratégicas do Estado ou demais formas de poder. Percebe-se como essas alegorias do poder aqui são deformadas ao ponto de fundirem mesmo na sintaxe a opressão religiosa e moral com os signos do consumo do capitalismo espetacular. Como que em uma dança, o eu lírico se esgueira entre essas alegorias, esquivando-se delas, mas também as agarrando. Trata-se de um jogo de sobrevivência que é assim encarado pelo eu lírico e, dada às circunstâncias, implica a possibilidade tanto de rejeitar quanto admitir essas figuras do poder. Forjar a própria identidade como malandro é enfrentar essa situação compreendendo os furos que permitem resistir a ela, mas também os fechamentos em que se deve se resignar

Tom Zé assume o eu lírico do malandro em outras faixas como "Profissão Ladrão", "Camelô" e "Não buzine que estou paquerando". Apesar de as duas primeiras serem relevantes por aprofundar na relação do malandro com outros tipos subalternos, é a terceira que nos interessa pela proposta de tensão que ela estabelece. Pois o proposto por Tom Zé aqui é o confronto entre os dois personagens amorais que ocuparam sua atenção em "Grande Liquidação" e que representam dois aspectos diversos da sociedade que se forma em São Paulo. Especificamente, o atrito entre o malandro ordinário e o homem de negócios inescrupuloso. Essa canção revela maior sutileza ao sugerir a tensão logo na sincronia entre a letra e a melodia. É um detalhe que deve ser considerado, em vista que boa parte da lírica se ocupa de descrever 
os percalços do referido capitalista, cuja ascensão burguesa só é possível mandando às favas qualquer limite ético ou moral.

Um homem de negócios

Não descansa, não:

Carrega na cabeça

Uma conta-corrente

Não perde um minuto

Sem o lucro na frente

Juntando dinheiro,

Imposto sonegando,

Passando contrabando,

Pois a grande cidade não pode parar (...)

A sua grande loja

Vai vender à mão farta

Doença terça-feira,

E o remédio na quarta,

Depois em Copacabana e Rua Augusta,

Os olhos bem abertos,

Nunca facilitar

O dólar na esquina

Sempre pode assaltar

Mas netos e bisnetos

Irão lhe sucedendo

Assim, sempre correndo,

Pois a grande cidade não pode parar (TOM ZÉ, 1968).

É uma aventura tipicamente burguesa em um mundo do capitalismo consagrado que permite transitar de São Paulo ao Rio de Janeiro com alguma tranquilidade. Contudo, essa tranquilidade de deslocamento não coincide com a noção de tempo, cuja máxima do "tempo é dinheiro" se traduz em uma disposição cada vez mais estreita de um sujeito cada vez mais estressado, apressado, atrapalhado e, claro, desonesto. Essa concepção tacanha de tempo é a razão de vivência que limita esse sujeito, o fecha dentro de sua própria perspectiva e é a fraqueza que permite ao eu lírico quebrar essa ordem de ser, mesmo que momentaneamente. É essa a essência do estribilho, uma quadra que resplandece a interrupção desse tempo do progresso por um ato singelo na cotidianidade.

Eu sei que o seu relógio

Está sempre lhe acenando

Mas não buzine

Que eu estou paquerando (TOM ZÉ, 1968).

A presença do eu lírico na narrativa se resume a esse estribilho, assim como o conflito sugerido entre ele e seu antagonista. Mas a força irônica que confere é realçada conforme sublinha a melodia: essa bricolagem entre marcha circense e orquestração caótica à moda do tropicalismo. Ela pontua de forma crescente e ao mesmo tempo cômico a potência desse simples flerte, que pode não ter tido sucesso em conquistar seu alvo intencional, mas conseguiu interromper o ciclo rotineiro de alguém que sequer estava associado diretamente ao ato. Conforme a ruptura da rotina desse homem de negócios significa quebrar com o melhor representante da ordem do capitalismo urbano e do tempo do progresso, isso alude à possibilidade de resistir dentro da ordinariedade cotidiana. Mais, o tom cômico, sarcástico, com que irrompe o estribilho significa expor ao escárnio as atribulações dessa vivência burguesa, logo sua verdade oculta, já que ela é amparada pela retórica do poder. Do que se extrai dessa perspectiva conflituosa, mas também singela, é algo significativo para as manipulações que Tom Zé opera no legado do rastro narrativo da canção paulistana. Para ele narrar na canção, elaborar alegorias, não é devolver uma experiência coletiva amparada em uma tradição sobrenatural. Ao contrário, é desencantar a própria modernidade do seu espetáculo próprio, cujo ofuscamento é conivente com a manutenção de uma ordem estabelecida capaz de administrar mesmo o próprio caos. 


\section{Referências}

ANDRADE, Mario de. Aspectos da música brasileira. 2. ed. São Paulo: Martins; Brasília: Instituto Nacional do Livro, 1975.

BENJAMIN, Walter. Obras escolhidas. Volume I - Magia e técnica, arte e política: ensaios sobre literatura e história da cultura. Tradução Sérgio Paulo Rouanet. 7. ed. São Paulo: Brasiliense, 2012.

BENJAMIN, Walter. Obras Escolhidas. Volume III - Charles Baudelaire: um lírico no auge do capitalismo. Tradução José Martins Barbosa, Hemerson Alves Batista. São Paulo: Brasiliense, 1989.

BERMAN, Marshall. Tudo que é sólido desmancha no ar: a aventura da modernidade. Tradução Carlos Felipe Moisés e Ana Maria L. Ioríatti. São Paulo: Companhia das Letras, 1986.

CAMPOS JUNIOR, Celso de. Adoniran: uma biografia. São Paulo: Globo, 2004

CANDIDO, Antônio. O discurso e a cidade. 4. ed. Rio de Janeiro: Ouro sobre o Azul, 2010. CERTEAU, Michel de. A invenção do cotidiano: 1. Artes de Fazer. Tradução Ephraim Ferreira Alvez. Petrópolis: Vozes, 1994.

DEBORD, Guy. A sociedade do espetáculo. Tradução Estela dos Santos Abreu. Rio de Janeiro: Contraponto, 1997.

GAGNEBIN, Jeanne Marie. História e narração em Walter Benjamin. São Paulo: Perspectiva, 2013

LE GOFF. Jacques. História e memória. Tradução Bernardo Leitão. 7. ed. Campinas: Editora Unicamp, 2013.

LÉVI-STRAUSS, Claude. Tristes trópicos. Tradução Rosa Freire d'Aguiar. São Paulo: Companhia das Letras, 1996.

LUKÁCS, Georg. A teoria do romance: um ensaio histórico-filosófico sobre as formas da grande épica. Tradução, posfácio e notas de José Marcus Mariani de Macedo. 2. ed. São Paulo: Duas Cidades; Editora 34, 2009.

NAVES, Santuza Cambraia. Canção popular no Brasil: a canção crítica. Rio de Janeiro: Civilização Brasileira, 2010.

NIETZSCHE, Friedrich. Genealogia da moral. Tradução, nota e prefácio de Paulo César Souza. São Paulo: Companhia das Letras, 2009.
MACHADO, Antonio Alcantara. Lira Paulistana. Revista do Arquivo Municipal, São Paulo, Departamento de Cultura, v. XVII, 1935.

ROCHA, Francisco. Adoniran Barbosa: o poeta da cidade. São Paulo: Ateliê Editorial, 2002

SARLO, Beatriz. Modernidade periférica: Buenos Aires 1920 e 1930. Tradução Júlio Pimentel Pinto. São Paulo: Cosac Naify, 2010.

TOM ZÉ. Grande liquidação. Recife: Rozenblit. 1968.

WISNIK, José Miguel. Sem receita. São Paulo: Publifolha, 2004.

Recebido em 29/06/2018

Aceito em 13/09/2018. 